\title{
Selection and characterization of mercury- independent activation mutants of the Tn501 transcriptional regulator, MerR
}

\author{
Julian Parkhill, † Blair Lawley, Jonathan L. Hobman and Nigel L. Brown
}

\author{
Author for correspondence: Nigel L. Brown. Tel: +44 121414 5467. Fax: +44 1214145907. \\ e-mail: n.l.brown@bham.ac.uk
}

Microbial Molecular

Genetics and Cell Biology Research Group, School of Biological Sciences, The University of Birmingham, Edgbaston, Birmingham B15 2TT, UK

\begin{abstract}
MerR is the transcriptional regulator of the mercury-resistance (mer) operon of transposon Tn501, acting at the mer promoter as both an activator in the presence of mercuric salts and a repressor in their absence. This paper reports a method for selection of constitutive activator mutants, which activate transcription in the absence of $\mathrm{Hg}^{\prime \prime}$, and the characterization of these MerR ${ }^{\mathrm{AC}}$ proteins. At least two mutations in the MerR protein were found necessary for strong mercury-independent activation, and these mutations lie in the $C$ terminal two-thirds of the MerR protein near the Hg"-binding cysteines. A triple mutation was shown to increase activation over the corresponding double mutations. All mutant proteins caused further activation in the presence of Hg". The data support a mechanism in which a conformational change of one or both MerR subunits in the homodimer drives a distortion of DNA bound to a helix-turn-helix structure in the $\mathbf{N}$-terminal region. $A$ mutation in this putative helix-turn-helix region severely reduced both the repressor and activator functions of MerR.
\end{abstract}

Keywords: repressor, activator, MerR family, transposon, mercury resistance

\section{INTRODUCTION}

MerR from Tn501 regulates expression of the mercuryresistance (mer) genes. In the absence of mercury it represses transcription of the mercury-resistance operon (merTPAD) from a single promoter, $\mathrm{P}_{\mathrm{T}}$, and in the presence of $\mathrm{Hg}^{\mathrm{II}}$ it activates transcription several hundredfold from the same promoter (Lund \& Brown, 1989a). It also maintains repression of its own promoter, $\mathrm{P}_{\mathrm{R}}$ (Lund et al., 1986). All these functions are carried out by a single MerR homodimer bound to the dyad symmetrical operator DNA between the -35 and -10 elements of $\mathrm{P}_{\mathrm{T}}$ (O'Halloran \& Walsh, 1987). Unlike most positively controlled promoters (Raibaud \& Schwartz, 1984), both the -35 and -10 elements of $P_{T}$ show good similarity to those of a canonical Escherichia coli $\sigma^{70}$ promoter $(5 / 6$ and $3 / 6$ respectively; Lund et al., 1986). However, the constitutive promoter activity of $P_{T}$ is very weak, due to the abnormally long spacer

\footnotetext{
†Present address: The Sanger Centre, Wellcome Trust Genome Campus, Hinxton, Cambridge CB10 1SA, UK.

¥Present address: School of Molecular and Medical Biosciences, Cardiff University, PO Box 920, Cardiff CF1 3XP, UK.
}

sequence between the promoter elements ( $19 \mathrm{bp}$ compared to $17 \pm 1$ bp in a typical promoter; Harley \& Reynolds, 1987), which is essential to the normal induction of the promoter (Lund \& Brown, 1989b; Parkhill \& Brown, 1990). Both MerR and RNA polymerase remain bound to the promoter during induction and some of the contacts of MerR with the DNA at the centre of the operator are altered on induction (O'Halloran et al., 1989; Frantz \& O'Halloran, 1990; Heltzel et al., 1990). Mutations in the RNA polymerase $\alpha$ and $\sigma^{70}$ subunits can affect the expression of $\mathrm{P}_{\mathrm{T}}$, but the basis for this is not known (Caslake et al., 1997) and, unlike a number of other activators, MerR does not contact site I of the $\alpha$-subunit (A. Ansari et al., unpublished data, quoted in Ishihama, 1993).

These observations led to a model for $\mathrm{P}_{\mathrm{T}}$ activation in which MerR, on binding $\mathrm{Hg}^{\mathrm{II}}$, directly causes a distortion of the DNA at the promoter, realigning the -10 and -35 elements and facilitating open complex formation by RNA polymerase (Lund \& Brown, 1989a; O'Halloran et al., 1989). O'Halloran and co-workers have shown that the addition of $\mathrm{Hg}^{\mathrm{II}}$ salts to the MerR-DNA complex caused unwinding by $33^{\circ}$ and straightening of a MerR-induced bend in the operator 
DNA (Ansari et al., 1992, 1995). This DNA distortion is due to MerR-dependent induction as shown by a mercury-independent activation mutant of MerR in vitro (Parkhill et al., 1993). The MerR protein contains an $\mathrm{N}$-terminal element predicted to form a helix-turn-helix motif (Dodd \& Egan, 1990) responsible for DNA binding, and four C-terminal cysteine residues, three of which are involved in tridentate binding of one $\mathrm{Hg}^{\mathrm{II}}$ ion per dimer (Ross et al., 1989; Shewchuk et al., 1989b; Wright et al., 1990; Utschig et al., 1995).

The model for regulation by MerR predicts that there should be two conformations of the protein: a repressor conformation which binds to DNA such that the -10 sequence cannot be contacted by RNA polymerase and the open transcriptional complex cannot be formed; and an activator conformation in which $\mathrm{Hg}^{\mathrm{II}}$ is bound to the C-terminal region of MerR and distorts the DNA, allowing RNA polymerase contacts to be made and transcription from $P_{T}$ to be initiated.

In the absence of structural data for MerR, evidence for the existence of two conformations of MerR can be obtained by isolating constitutive activator and constitutive repressor mutants. Ross et al. (1989) isolated mutants of Tn21 MerR with altered repression and activation phenotypes, and Parkhill et al. (1993) reported the construction of a strong mercury-independent activator mutant of Tn501 MerR, which in the absence of $\mathrm{Hg}^{\mathrm{II}}$ caused the same distortion of mer operator DNA as did the wild-type $\mathrm{Hg}^{\mathrm{II}}-\mathrm{MerR}$ complex. Comess et al. (1994) generated a similar mutant (in a synthetic merR gene) combining $\mathrm{A} 89 \mathrm{~V}$ and $\mathrm{S} 86 \mathrm{C}$ changes. The formal possibility exists that these few mutations directly affect the interaction of MerR with RNA polymerase or with DNA and activate the DNA without changing the conformation of MerR. We therefore attempted to isolate a series of mutant MerR proteins to test further the two-conformation hypothesis for the action of MerR.

In this paper we describe the isolation by random and site-directed mutagenesis of constitutively activating MerR mutants and the characterization of the mutants obtained. We also report a mutation affecting DNA binding by MerR. The hypothesis that $\mathrm{Hg}^{\mathrm{II}}$ acts in promoter regulation by altering the equilibrium between two conformational states of MerR, one repressing and one activating, is supported by distribution of the mutations in the protein and by the increasing activation observed within a single-double-triple mutation series and by the further activation seen with all mutants in the presence of $\mathrm{Hg}^{\mathrm{II}}$.

\section{METHODS}

Bacterial strains. The bacterial strains used in this study are listed in Table 1 . They were grown in LB $(1.0 \%$ tryptone, $0.5 \%$ yeast extract, $0.5 \% \mathrm{NaCl}, \mathrm{pH} 7.5$ ) containing $0.2 \%$ glucose, or in supplemented M9 minimal medium (Miller, 1972 ) containing $0.2 \%$ glucose, thiamin $\left(20 \mu \mathrm{g} \mathrm{ml}^{-1}\right)$ and $0.2 \%$ Casamino acids. Dehydrated media were purchased from Becton Dickinson or LabM. Antibiotics were used at the following concentrations: carbenicillin (Cb), $250 \mu \mathrm{g} \mathrm{ml} l^{-1}$; chloramphenicol $(\mathrm{Cm}), 35 \mu \mathrm{g} \mathrm{ml}^{-1}$; kanamycin sulphate $(\mathrm{Kn})$, $50 \mu \mathrm{g} \mathrm{ml}^{-1}$; trimethoprim lactate (Tp), $25 \mu \mathrm{g} \mathrm{ml}^{-1}$; tetracycline (Tc), $15 \mu \mathrm{g} \mathrm{ml}^{-1}$ (except as described in the text when used for assaying the expression of $\mathrm{P}_{\mathrm{T}}:: \mathrm{Tc}^{\mathrm{r}}$ fusions). X-Gal (Sigma) was used at a concentration of $34 \mu \mathrm{g} \mathrm{ml}^{-1}$.

Plasmids and vectors. Plasmids used in this study are listed in Table 1. A reporter plasmid, pMU-HT108, containing a $\mathrm{P}_{\mathrm{T}}$ : :lacZ transcriptional fusion, was constructed. This was generated by initially cloning a 108 bp HpaII-TaqI fragment containing the merOP region from pJOE114 (Brown et al., 1983 ) into the AccI site of pUC19 (Yanich-Perron et al., 1985). A recombinant plasmid with the insert in the desired orientation was selected and the insert was subcloned as a $B a m$ HI-HindIII fragment upstream of the promoterless lacZ gene in the low-copy-number IncW plasmid pMU2385 (Praszkier et al., 1992), such that transcription of the lac Z gene was driven by the $P_{T}$ promoter. A second $P_{T}$ transcriptional fusion $\left(\mathrm{P}_{\mathrm{T}}\right.$ : tet $\mathrm{C}$ ) was available in plasmid $\mathrm{pBR}-\mathrm{EA}-1$ (Lund \& Brown, 1989b), which confers on cells resistance to high levels of tetracycline only when the promoter $P_{T}$ is induced (e.g. in the presence of a plasmid expressing wild-type MerR and inducing concentrations of $\mathrm{HgCl}_{2}$ ).

To provide the merR gene in trans to these tetC and lac $Z$ reporter plasmids, a $\mathrm{Kn}^{\mathrm{r}} \mathrm{Tc}^{\mathrm{s}}$ derivative of plasmid $\mathrm{pACYC184}$ (Chang \& Cohen, 1978) was constructed. pACYC184 has the p15 origin of replication and is therefore compatible with both pBR-EA-1 and pMU-HT108, but a Tc s derivative was required to allow detection of the Tcr status of pBR-EA-1. The $\mathrm{Kn}^{r}$ gene and promoter from $\mathrm{pBGS18}{ }^{+}$(Spratt et al., 1986) were used to provide a selectable marker for the pACYC184 derivative; these were isolated as a $1.5 \mathrm{~kb}$ MluI fragment, the 5 ' overhangs were filled in with Klenow DNA polymerase, and the fragment was cloned into the HinclI site of pUC19. An insert of the desired orientation was recloned as a BamHI-HindIII fragment between the BamHI and HindIII sites of pACYC184, removing the promoter and $5^{\prime}$ end of the pACYC184 $\mathrm{Tc}^{r}$ gene in the process. The resulting plasmid (pACK15) was confirmed to be $\mathrm{Cm}^{r} \mathrm{Kn}^{\mathrm{r}} \mathrm{Tc}^{\mathrm{s}}$. The individual wild-type and mutant (A89V, S131L and A-S) merR genes (Parkhill et al., 1993) were cloned into this vector at the $E c o R I$ site in the $\mathrm{Cm}^{\mathrm{r}}$ gene, so that the merR gene was expressed from the constitutive chloramphenicol acetyltransferase promoter. These plasmids were designated pACK-90-16, pACK-A89V, pACK-S131L and pACK-A-S, respectively.

pACYC184-based plasmids containing mutated merR genes were constructed by cloning mutagenized DNA fragments from the vectors pMa90-16, pMcA89V and pMcS131L into pACYC184 or pACK15. These were designated pAC-mut and pACK-mut, respectively, where $m u t$ refers to the mutation in MerR, as determined by sequence analysis.

Enzymes and chemicals. Restriction enzymes, T4 DNA ligase and T4 polynucleotide kinase were purchased from Bethesda Research Laboratories, New England Biolabs, or Boehringer Mannheim, and were used according to the manufacturers' instructions. Klenow DNA polymerase was purchased from Amersham and Sequenase from United States Biochemical Corporation (USB). NEN DuPont supplied $\left[\gamma^{32} \mathrm{P}\right]$ ATP. Chemical reagents were obtained from Fisons, Sigma or Boehringer Mannheim and were analytical grade wherever possible.

DNA manipulations. DNA manipulations were carried out largely as described by Sambrook et al. (1989). Preparative electrophoresis for purification of DNA fragments was carried out on a $6 \%$ or $8 \%$ ( $30: 1$ cross-linking) polyacrylamide gel in 
Table 1. Bacterial strains and plasmids used in this study

\begin{tabular}{|c|c|c|}
\hline E. coli strain & Genotype & Reference \\
\hline $\mathrm{CSH} 26 \Delta r e c A$ & ara $\Delta$ (lac-pro) thi $\Delta r e c A$ & Miller (1972) \\
\hline WK6 & $\Delta$ (lac-pro) galE strA $\mathrm{F}^{\prime}\left[\operatorname{lacl}^{\mathrm{q}} \mathrm{Z} \Delta \mathrm{M} 15\right.$ pro $\left.A^{+} B^{+}\right]$ & Stanssens et al. (1989) \\
\hline WK6mutS & As above but mutS215:: $\operatorname{Tn} 10 ; \mathrm{Tc}^{\mathrm{r}}$ & Stanssens et al. (1989) \\
\hline Plasmid & Properties & Reference \\
\hline pACYC184 & $\begin{array}{l}\text { Cloning vector with p15a origin of replication; } \mathrm{Cm}^{\mathrm{r}} \\
\mathrm{Tc}^{\mathrm{r}}\end{array}$ & $\begin{array}{l}\text { Chang \& Cohen } \\
(1978)\end{array}$ \\
\hline pAC-mut & $\begin{array}{l}\text { pACYC184 with EcoRI fragment encoding a mutant } \\
\text { MerR cloned into } \mathrm{Cm}^{r} \text { gene; } \mathrm{Tc}^{\mathrm{r}}\end{array}$ & This study \\
\hline pAC-90-16 & $\begin{array}{l}\text { pACYC184 with EcoRI fragment encoding wild-type } \\
\text { MerR cloned into } \mathrm{Cm}^{r} \text { gene; } \mathrm{Tc}^{\mathrm{r}}\end{array}$ & This study \\
\hline pACK 15 & $\begin{array}{l}\text { pACYC184 with } \mathrm{Kn}^{r} \text { gene replacing } \mathrm{Tc}^{\mathrm{r}} \text { gene } ; \mathrm{Cm}^{\mathrm{r}} \\
\mathrm{Kn}^{\mathrm{r}}\end{array}$ & This study \\
\hline pACK-mut & $\begin{array}{l}\text { pACK } 15 \text { with EcoRI fragment encoding a mutant } \\
\text { MerR cloned into } \mathrm{Cm}^{\mathrm{r}} \text { gene } ; \mathrm{Kn}^{\mathrm{r}}\end{array}$ & This study \\
\hline pACK-90-16 & $\begin{array}{l}\text { pACK } 15 \text { with EcoRI fragment encoding wild-type } \\
\text { MerR cloned into } \mathrm{Cm}^{\mathrm{r}} \text { gene } ; \mathrm{Kn}^{\mathrm{r}}\end{array}$ & This study \\
\hline pBGS18+ & $\begin{array}{l}\text { Derivative of pUC19 with } \mathrm{Kn}^{\mathrm{r}} \text { gene replacing } \mathrm{Cb}^{\mathrm{r}} \text {; } \\
\mathrm{Kn}^{r}\end{array}$ & Spratt et al. (1986) \\
\hline pBR-EA-1 & $\begin{array}{l}\text { Derivative of pBR322 in which the } \mathrm{Tc}^{r} \text { gene is } \\
\text { expressed from } \mathrm{P}_{\mathrm{T}} ; \mathrm{Cb}^{r}\end{array}$ & $\begin{array}{l}\text { Lund \& Brown } \\
\text { (1989b) }\end{array}$ \\
\hline pJOE114 & $\operatorname{Tn} 501::$ pBR322 fusion; $\mathrm{Cb}^{r}$ & Brown et al. (1983) \\
\hline pKK223.3 & Vector for IPTG-inducible protein expression; $\mathrm{Cb}^{\mathbf{r}}$ & Amann et al. (1983) \\
\hline pKK-mut & $\begin{array}{l}\text { Derivative of pTO90-16 containing a mutant merR } \\
\text { gene for overexpression of mutant MerR; } \mathrm{Cb}^{r}\end{array}$ & This work \\
\hline $\mathrm{pMa} / \mathrm{c} 5-8$ & Mutagenesis vectors; $\mathrm{Cb}^{\mathrm{r}} / \mathrm{Cm}^{\mathrm{r}}$ & Stanssens et al. (1989) \\
\hline pMa90-16 & MerR fragment from pTO90-16 cloned into pMa5-8 & Parkhill et al. (1993) \\
\hline $\begin{array}{l}\text { pMcA89V, } \\
\text { pMcS131L }\end{array}$ & $\begin{array}{l}\text { Derivatives of } \mathrm{pMa} 90-16 \text { bearing site-specific } \\
\text { mutations in } m e r R ; \mathrm{Cm}^{\mathrm{r}}\end{array}$ & Parkhill et al. (1993) \\
\hline pMU2385 & $\begin{array}{l}\text { Single-copy promoter probe vector with promoterless } \\
\text { lacZ gene; } \mathrm{Tp}^{\mathrm{r}}\end{array}$ & Praszkier et al. (1992) \\
\hline pMU-HT108 & pMU2385 with $\mathrm{P}_{\mathrm{T}}$ transcribing the lacZ gene; $\mathrm{Tp}^{\mathrm{r}}$ & This study \\
\hline $\mathrm{pRZH}-2$ & Promoter probe vector with $\mathrm{P}_{\mathrm{T}}$ : lac $\mathrm{Z}$ fusion; $\mathrm{Kn}^{\mathrm{r}}$ & Lund et al. (1986) \\
\hline $\mathrm{pRZH}-18$ & Promoter probe vector with $\mathrm{P}_{\mathrm{T}}$ : $: \operatorname{lac} \mathrm{Z}$ fusion; $\mathrm{Kn}^{\mathrm{r}}$ & Lund et al. (1986) \\
\hline pTO90-16 & $\begin{array}{l}\text { MerR overexpression construct derived from } \\
\text { pKK223.3; } \mathrm{Cb}^{r}\end{array}$ & $\begin{array}{l}\text { O'Halloran \& Walsh } \\
\text { (1987) }\end{array}$ \\
\hline pUC19 & Cloning vector $\mathrm{Cb}^{\mathrm{r}}$ & $\begin{array}{l}\text { Yanisch-Perron et al. } \\
\text { (1985) }\end{array}$ \\
\hline
\end{tabular}

a mini-Protein II gel system (Bio-Rad). DNA was stained with ethidium bromide, visualized briefly under UV illumination, eluted by crushing the excised polyacrylamide fragment and soaking for several hours in elution buffer $(0.5 \mathrm{M}$ ammonium acetate, $10 \mathrm{mM}$ magnesium acetate, $0.1 \%$ SDS, $0.1 \mathrm{mM}$ EDTA) and then purified by phenol extraction and ethanol precipitation.

Hydroxylamine mutagenesis. Plasmid DNA $(2-10 \mu \mathrm{g})$ was incubated in $100 \mu \mathrm{l} 50 \mathrm{mM}$ sodium pyrophosphate $(\mathrm{pH} 7 \cdot 0$ ), $100 \mathrm{mM} \mathrm{NaCl}, 2 \mathrm{mM}$ EDTA, $1 \mathrm{M}$ hydroxylamine at $70^{\circ} \mathrm{C}$. Aliquots $(25 \mu \mathrm{l})$ were removed at $15,30,60$ and $120 \mathrm{~min}$ and added to $1 \mathrm{ml}$ precipitation solution $(150 \mathrm{mM}$ sodium acetate, $20 \mu \mathrm{g} \mathrm{tRNA} \mathrm{m} \mathrm{l}^{-1}, 50 \%$ propan-2-ol). The DNA was recovered by centrifugation at $12000 \mathrm{~g}$ for $15 \mathrm{~min}$, and the pellet was washed with $70 \%$ ethanol before being dried under vacuum. The DNA was resuspended in $50 \mu \mathrm{l}$ Tris $/ \mathrm{HCl}(10 \mathrm{mM}, \mathrm{pH}$
7.5), $1 \mathrm{mM}$ EDTA, and used in transformation of recipient $E$. coli cells. For selection of non-activating mutants from plasmid pAC-90-16, the strain E. coli CSH26ArecA(pRZH-18) (Lund et al., 1986) was transformed and transformants were selected on minimal medium containing $\mathrm{HgCl}_{2}\left(1.0 \mu \mathrm{g} \mathrm{ml}^{-1}\right)$ and $\mathrm{Cb}, \mathrm{Tc}$ and $\mathrm{X}-\mathrm{Gal}$ at the concentrations given above. For selection of activating mutations from plasmids pACK-90-16, pACK-A89V and pACK-S131L, the strain E. coli CSH264recA(pMU-HT108, pBR-EA-1) was used and transformed cells were plated onto supplemented minimal media containing $\mathrm{Cb}, \mathrm{Kn}, \mathrm{Tp}, \mathrm{X}-\mathrm{Gal}$ (at the concentrations given above) and $\mathrm{Tc}\left(5\right.$ or $\left.10 \mu \mathrm{g} \mathrm{ml}^{-1}\right)$.

DNA sequencing. DNA sequence analysis was by the chain termination method (Sanger et al., 1977) using modified T7 DNA polymerase, or with Sequenase (USB) using the modified Sanger protocol supplied by the manufacturer. Both reactions 
were performed on single-stranded templates generated from the mutagenesis vector $\mathrm{pMa} / \mathrm{c} 5-8$ by superinfection, as described by Stanssens et al. (1989). Oligonucleotide sequencing primers were complementary to the end of the multiple cloning site of $\mathrm{pMa} / \mathrm{c5-8}$, or to sequences within the merR gene.

Site-directed mutagenesis. This was performed using the gapped-duplex method of Stannsens et al. (1989). The merR gene was cloned into the EcoRI site of $\mathrm{pMa} / \mathrm{c5}-8$ and mutagenized using the following oligonucleotides: D78N $\left(5^{\prime}\right.$ GGGTGCCATTCTCCAGCCG), E77K (5'-TGCCATCCTTCAGCCGCAG), E77K-D78N (5'-TGCCATTCTTCAGCCGCAG), L74Q (5'-TCCAGCCGCTGCAGCTCGG), P127L (5'-GCGATCAGCAGGCAGGAAA), where the underlined letters show the nucleotides altered from the wildtype $\operatorname{mer} R$ gene.

$\boldsymbol{\beta}$-Galactosidase assays. These were carried out as described by Miller (1972). Strains containing the plasmid(s) to be assayed were grown overnight in supplemented M9 medium in the presence of appropriate antibiotics. The cultures were then diluted 1:50 into fresh medium and grown with shaking at $37^{\circ} \mathrm{C}$ until the $\mathrm{OD}_{600}$ was between 0.4 and 0.8 . If the strains were to be induced with $\mathrm{Hg}^{\mathrm{II}}, \mathrm{HgCl}_{2}$ was added to a final concentration of $1.8 \mu \mathrm{M} 1 \mathrm{~h}$ before assaying the culture. All assays were carried out in triplicate.

Purification of MerR proteins. Wild-type MerR was purified according to a modification of the protocol described by Parkhill et al. (1993). Cells containing pTO90-16 (for wildtype MerR) or isogenic derivatives containing mutant $m e r R$ genes (the pKK-mut series) were grown in $800 \mathrm{ml} \mathrm{LB}, 0.2 \%$ glucose with shaking at $37^{\circ} \mathrm{C}$ to $\mathrm{OD}_{600}=0 \cdot 7$, isopropylthiogalactoside was added to $50 \mu \mathrm{M}$, and growth continued for a further $1 \mathrm{~h}$. Cells were harvested by centrifugation and resuspended at $0.5 \mathrm{~g} \mathrm{ml}^{-1}$ in buffer $A(100 \mathrm{mM}$ Tris $/ \mathrm{HCl}, \mathrm{pH}$ $8 \cdot 0,10 \mathrm{mM} \mathrm{MgCl}_{2}, 1 \mathrm{mM}$ EDTA, $5 \mathrm{mM}$ DTT, $10 \%$ glycerol, containing protease inhibitors). Cells were disrupted by sonication on ice for a total of $8 \mathrm{~min}$ in $30 \mathrm{~s}$ bursts separated by a cooling period of $2.5 \mathrm{~min}$. The sonicate was centrifuged $\left(24000 \mathrm{~g}, 30 \mathrm{~min}, 4^{\circ} \mathrm{C}\right)$ and the supernatant was discarded. The pellet was washed with $20 \mathrm{ml}$ buffer $A$ and centrifuged again. The pellet was then suspended in buffer $Z(20 \mathrm{mM}$ Tris $/ \mathrm{HCl}, \mathrm{pH} 7.4,10 \mathrm{mM} \mathrm{MgCl}_{2}, 0.1 \mathrm{mM}$ EDTA, $1 \mathrm{mM}$ DTT, $10 \%$ glycerol) containing $1 \mathrm{M} \mathrm{NaCl}$ equal to the original volume of buffer $\mathrm{A}$ used. The suspension was incubated for $5 \mathrm{~min}$ at $4{ }^{\circ} \mathrm{C}$ and centrifuged $(24000 \mathrm{~g}, 30 \mathrm{~min}$, $4{ }^{\circ} \mathrm{C}$ ). Streptomycin sulphate was slowly added to the supernatant to a final concentration of $0.2 \%$ and the suspension was incubated for $30 \mathrm{~min}$ at $4{ }^{\circ} \mathrm{C}$ before the precipitate was collected by centrifugation $\left(24000 \mathrm{~g}, 30 \mathrm{~min}, 4^{\circ} \mathrm{C}\right)$ and discarded. Ammonium sulphate was slowly added to the supernatant to $50 \%$ saturation and the precipitate was allowed to form over $30 \mathrm{~min}$ at $4{ }^{\circ} \mathrm{C}$. The precipitate was collected by centrifugation as before and redissolved in $10 \mathrm{ml}$ buffer $\mathrm{Z} / 1 \mathrm{M}$ $\mathrm{NaCl}$ (for $800 \mathrm{ml}$ culture).

The protein solution was diluted 10 -fold with buffer $\mathrm{Z}$ and loaded onto a heparin sulphate column pre-equilibrated in buffer $\mathrm{H}(20 \mathrm{mM}$ sodium phosphate, $\mathrm{pH} 6 \cdot 0,0 \cdot 1 \mathrm{M} \mathrm{NaCl}$, $0.1 \mathrm{mM}$ EDTA, $2 \mathrm{mM}$ DTT, $10 \%$ glycerol). The column was washed with buffer $\mathrm{H}$ and eluted with a gradient of $0.1-0.5 \mathrm{M}$ $\mathrm{NaCl}$ in buffer $\mathrm{H}$. Fractions containing the highest concentrations of MerR were identified by SDS-PAGE, made $50 \%$ in glycerol and stored under nitrogen at $-20^{\circ} \mathrm{C}$. To minimize oxidation of cysteine residues, all buffers were purged with nitrogen gas, filtered through $0.45 \mu \mathrm{m}$ filters and then degassed before use.
Protein concentrations were measured by the method of Bradford (1976) on a routine basis. These were standardized against the Lowry method to provide comparability with concentrations determined in other studies (Shewchuk et al., 1989c; Frantz \& O'Halloran, 1990; Parkhill et al., 1993; Comess et al., 1994), as the Bradford assay gives an apparent sevenfold lower concentration for MerR than does the Lowry method when using bovine serum albumin as a standard.

Gel retardation assay. DNA fragments following EcoRI/BamHI digestion of $2 \mu \mathrm{g} \mathrm{pRZH-2} \mathrm{DNA} \mathrm{(Lund} \mathrm{et} \mathrm{al.,} \mathrm{1986)}$ were end-labelled by incubation with $\left[\gamma^{32} \mathrm{P}\right]$ ATP $(3000$ $\mathrm{Ci} \mu \mathrm{mol}^{-1} ; 37 \mathrm{TBq} \mu \mathrm{mol}^{-1}$ ) and $\mathrm{T} 4$ polynucleotide kinase, according to the manufacturer's protocol. The end-labelled $200 \mathrm{bp}$ EcoRI-BamHI fragment containing the mer operator was purified by electrophoresis on $8 \%$ acrylamide gels as described above, but the fragment was visualized by brief autoradiography. The DNA concentration was calculated from the known starting concentration of DNA and by following incorporated radioactivity.

Aliquots of the purified DNA fragment $(1 \mathrm{fmol})$ were incubated with increasing concentrations of protein. Protein-DNA complexes were formed in $20 \mu$ incubation buffer $[10 \mathrm{mM}$ Tris $/ \mathrm{HCl} \mathrm{pH} 8,100 \mathrm{mM}$ potassium glutamate, $0.1 \mathrm{mM}$ EDTA, $1 \mathrm{mM} \mathrm{CaCl}, 5 \%$ (v/v) glycerol, $1 \mathrm{mM} \mathrm{DTT} \mathrm{and}$ $100 \mu \mathrm{g} \mathrm{BSA} \mathrm{ml} \mathrm{m}^{-1}$ ] for $1 \mathrm{~h}$ at $10^{\circ} \mathrm{C}$. $\mathrm{HgCl}_{2}$ was present at $0.75 \mu \mathrm{M}$ where required. Following incubation the complexes were resolved on $6 \%(37 \cdot 5: 1)$ native polyacrylamide gels which were pre-run at $300 \mathrm{~V}$ for at least $45 \mathrm{~min}$ in a cold room. The samples were loaded on the gels and were then run at $300 \mathrm{~V}$ for $2 \cdot 5 \mathrm{~h}$.

DNA fragments were visualized using a Molecular Dynamics phosphorimager and the intensities of fragments of different mobility were analysed with the Imagequant software. The fraction of radioactivity in the band that represents specific protein-DNA complexes was plotted against concentration of the respective proteins on a semi-logarithmic graph. The apparent $K_{\mathrm{D}}$ in such a plot is the concentration of the protein at half-maximal binding.

\section{RESULTS}

\section{Selection of activating MerR mutants}

Previous selection procedures using a single copy of $\mathrm{P}_{\mathrm{T}}$ linked to a selectable reporter had isolated only $\mathrm{P}_{\mathrm{T}}$ promoter-up mutations, and single-step random mutagenesis of wild-type MerR had not revealed the desired strong mercury-independent activation mutants of MerR. The selection procedure based on two $P_{T}$ gene fusions to independent selectable markers, tet $C$ and lacZ (Fig. 1), should avoid the isolation of promoter-up mutations and allow infrequent mutations to be isolated. Colonies that were $\operatorname{tet} \mathrm{C}^{+}$lac $\mathrm{Z}^{+}$would be likely to contain activating mutations in the merR gene, rather than separate promoter-up mutations in the two $\mathrm{P}_{\mathrm{T}}$ promoters.

The selection procedure was tested by transforming existing pACK-merR plasmids into E. coli $\mathrm{CSH} 26-$ $\Delta r e c A$ (pMU-HT108, pBR-EA-1). The resulting transformants were tested for $T c^{r}$ in the presence and absence of mercury. The wild-type and single mutants (A89V or $\mathrm{S} 131 \mathrm{~L}$ ) could grow on $15 \mu \mathrm{g} \mathrm{Tc} \mathrm{ml} l^{-1}$ only in the presence of $\mathrm{HgCl}_{2}$. The positive control strain expressing the 


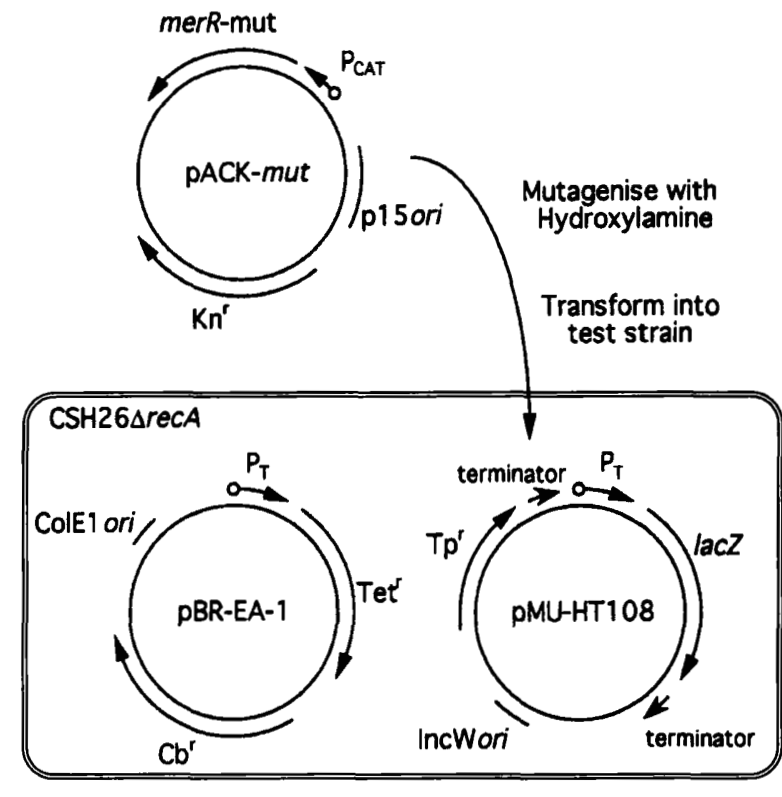

Fig. 1. Diagram showing the selection procedure for isolation of activating merR mutants. Consitutively activating mutations cause expression of tetracycline resistance and $\beta$-galactosidase activity. Details of the selection are given in the text.

constitutive activator MerR(A-S) (Parkhill et al., 1993), however, could grow on $15 \mu \mathrm{g} \mathrm{Tc} \mathrm{ml} l^{-1}$ in the absence of $\mathrm{HgCl}_{2}$. In each case the expression of $\beta$-galactosidase corresponded with the expression of tetracycline resistance (i.e. colonies showing high-intensity blue colour were more tetracycline resistant than colonies showing lower intensity blue colour).

Each of the plasmids pACK-90-16 (wild-type), pACKA89V and pACK-S131L (Table 1) was mutagenized with hydroxylamine, and used to transform $E$. coli CSH26$\Delta r e c A$ (pMU-HT108, pBR-EA-1). After 2-3 dincubation at $37^{\circ} \mathrm{C}$ on supplemented minimal media containing $\mathrm{Cb}, \mathrm{Kn}, \mathrm{Tp}, \mathrm{X}-\mathrm{Gal}$ and Tc $\left(5\right.$ or $\left.10 \mu \mathrm{g} \mathrm{m}^{-1}\right)$, blue colonies were picked and plated in replicates on the same medium with or lacking Tc $\left(10 \mu \mathrm{g} \mathrm{ml}^{-1}\right)$, together with E. coli CSH26 recA(pMU-HT108, pBR-EA-1) containing either of the parent plasmids or pACK-A-S, as controls. Colonies that were tetracycline resistant and showed strong $\beta$-galactosidase activity were selected for further characterization. Seven such colonies were isolated using pACK-A89V as the parent plasmid and two using pACK-S131L; none was detected when pACK-90-16 was used.

\section{Characterization of activating MerR mutants}

The selected mutant colonies were grown in liquid culture and pACK-merR DNA was prepared by alkaline lysis. The $500 \mathrm{bp} m e r R$-containing EcoRI fragments were purified, cloned into pACYC184 (Chang \& Cohen, 1978), and used to transform E. coli CSH26 rrecA(pRZH-18) (Lund et al., 1986). For each mutant a transformant was identified in which the merR fragment in the recombinant plasmid was in the correct orientation to be transcribed from the CAT promoter. These transformants were assayed for $\beta$-galactosidase activity in the presence and absence of mercury (Fig. 2). This ensured that effects were entirely due to mutations within the merR gene and not to mutations elsewhere on the mutagenized plasmid or to induced changes in the host chromosome during the initial selection. In addition, each mutant merR gene was subcloned from the pACYC184 construct into M13mp19 in both orientations and fully sequenced to determine the site and number of mutations present in the gene. The positions of each mutation in the MerR protein are shown in Fig. 3 .

Using MerR S131L as the parent, the additional mutations R62Q or V124A caused weak activating phenotypes, each with uninduced $\beta$-galactosidase activities about $10 \pm 7 \%$ of the induced wild-type activity. This compares with the more strongly activating phenotype of the A89V-S131L mutant MerR of about $50 \pm 10 \%$ and the S131L uninduced activity of $2 \cdot 2 \pm 0.9 \%$ of induced wild-type activity. When $\mathrm{A} 89 \mathrm{~V}$ was used as the parent, further mutations L74Q, E77K, G79V, G79S, T80P and P127L were separately isolated. The mutants containing A89V with G79D, G79S, or T80P had only weakly activating phenotypes in the absence of $\mathrm{Hg}^{\mathrm{II}}$ $(4.3 \pm 1.5 \%, 4.8 \pm 1.6 \%$ and $2.8 \pm 0.8 \%$ of induced wildtype activity, respectively) and were induced in the presence of $\mathrm{Hg}^{\text {II }}$ to a level similar to that of the wild-type MerR. In the absence of $\mathrm{Hg}^{\text {II }}$ the difference between mutants containing these double mutations and that containing the A89V mutation alone $(1.4 \pm 0.5 \%$ of wild-type induced activity) was small. Mutations containing A89V with $\mathrm{L} 74 \mathrm{Q}$, E77K, or P127L were more strongly activating in the absence of $\mathrm{Hg}^{\mathrm{II}}(39 \pm 17 \%$, $48 \pm 5.7 \%$ and $34 \pm 7.0 \%$ of induced wild-type activity, respectively).

One strain was found to contain two mutations, E77K and $D 78 \mathrm{~N}$, in addition to the A89V mutation of the parent, and this triple mutation gave the most strongly activating phenotype of all $(86 \pm 17 \%$ of induced wildtype activity). Each of the mutations was recreated as a single or double mutation using the procedure of Stanssens et al. (1989) on the plasmid pMa90-16 (Parkhill et al., 1993), with the oligonucleotides described in Methods. Two other mutations which showed high $\mathrm{Hg}^{\text {II }}$-independent induction when present with the A89V mutation, namely $\mathrm{L} 74 \mathrm{Q}$ and $\mathrm{P} 127 \mathrm{~L}$, were also recreated as single mutations in the mer $R$ gene. These mutant merR genes were sequenced and were also subcloned into pACYC184 for $\beta$-galactosidase assay as described above. The results of the $\beta$-galactosidase assays are shown in Fig. 2.

Of the single mutants, L74Q showed the strongest activation in the absence of $\mathrm{Hg}^{\mathrm{II}}(4.9 \pm 0.1 \%$ induced wild-type activity), the remainder being E77K, $2 \cdot 2 \pm$ $0.6 \% ; \mathrm{D} 78 \mathrm{~N}, 0.74 \pm 0.06 \% ; \mathrm{P} 127 \mathrm{~L}, 0.75+0.12 \%$. The two newly created double mutants, A89V-D78N and D78N-E77K, mediated stronger $\mathrm{Hg}^{\mathrm{II}}$-independent ac- 


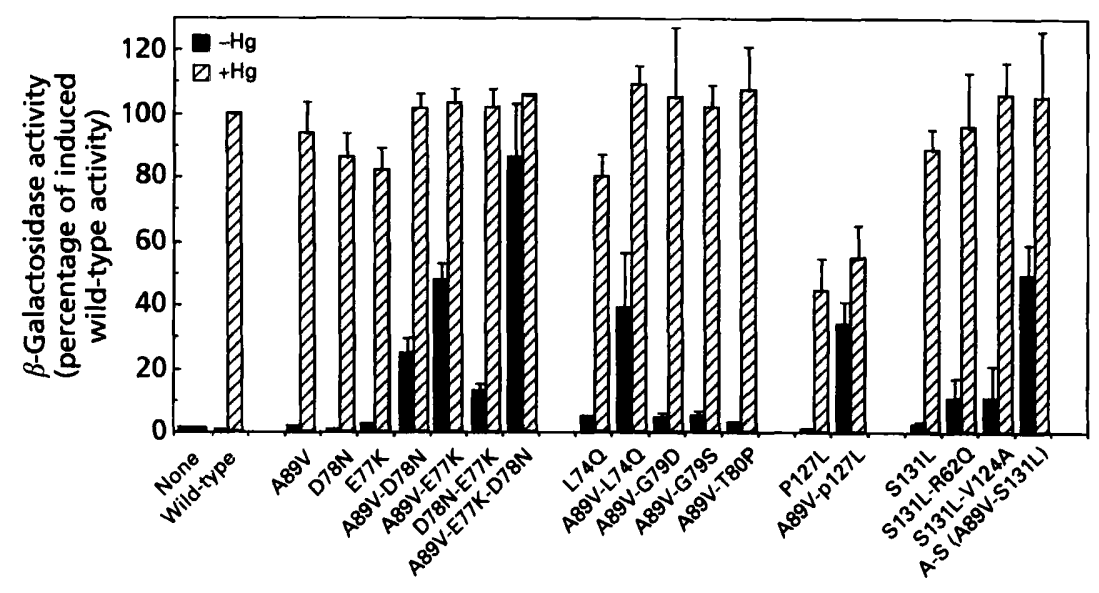

Fig. 2. $\beta$-Galactosidase assays of $E$. coli CSH26 $\triangle$ recA(pRZH-18) strains carrying mutant activating merR genes in the presence (hatched) and absence (solid) of $\mathrm{Hg}^{\prime \prime}$. Each strain carries the merR gene cloned in pACYC184 and expressed from the CAT promoter. Each assay was carried out in triplicate and standard deviations are shown. All single mutants were created by site-directed mutagenesis, as were mutants D78N-E77K and A89V-D78N; the construction of A89V-S131L has been described (Parkhill et al., 1993). All other mutants were obtained by random mutagenesis from either $\mathrm{A} 89 \mathrm{~V}$ or $\mathrm{S} 131 \mathrm{~L}$ as parent.

1 MENNLENLTI GVFAKAAGVN VETIRFYQRK GLLLEPDKPY GSIRRYGEAD

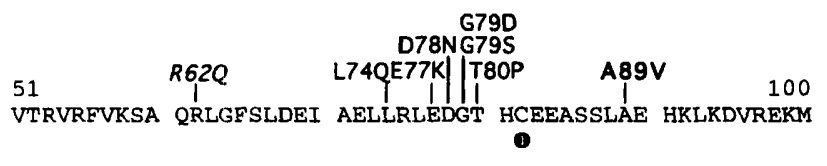
101
ADLARMEAVI SELVCACHAR RGNVSCPLIA SLQGGASLAG SAMP

Fig. 3. Positions of activating mutations of Tn501 MerR. The putative helix-turn-helix and the mercury-binding cysteine residues are marked. Mutations R62Q and V124L (and A89V) show enhanced mercury-independent activation when present with S131L; the remaining mutations (including S131L) show enhanced mercury-independent activation when paired with A89V.

tivation than any of the single mutants $(26 \pm 4 \%$ and $14 \pm 2 \%$ ), although these levels were lower than those observed for the A89V-E77K or triple mutant. These compare with uninduced wild-type activities of $0.48 \pm$ $0 \cdot 16 \%$. All the single mutants had lower induced activities than the wild-type MerR, but only P127L (at $45 \pm 10 \%$ ) showed an induced activity in the presence of $\mathrm{Hg}^{\overline{I 1}}$ of less than $80 \%$ of the induced wild-type value. This poor induction in the presence of $\mathrm{Hg}^{\mathrm{II}}$ was also seen in the A89V-P127L mutant $(55 \pm 11 \%)$.

\section{DNA binding by constitutive activator mutant and wild-type MerR proteins}

DNA-binding studies were carried out using a $200 \mathrm{bp}$ DNA fragment containing the wild-type $P_{T}$ operator region and different concentrations of the wild-type MerR protein or constitutive activator mutants. Gel retardation assays indicated that wild-type MerR binds the operator site with apparent $K_{\mathrm{D}}$ values of $2 \times 10^{-10} \mathrm{M}$ in the presence of $\mathrm{Hg}^{\mathrm{II}}$ and $1 \times 10^{-10} \mathrm{M}$ in the absence of $\mathrm{Hg}^{\text {II }}$. The binding affinities of the mutant proteins tested are shown in Table 2.
Table 2. Equilibrium dissociation constants of the mutant MerR proteins

\begin{tabular}{|lcc|}
\hline Protein & \multicolumn{2}{c|}{$K_{\mathrm{D}}(\mathrm{M})$} \\
\cline { 2 - 3 } & $+\mathrm{Hg}$ & $-\mathrm{Hg}$ \\
\hline Wild-type & $1.9 \times 10^{-10}$ & $1.0 \times 10^{-10}$ \\
A89V & $1.7 \times 10^{-10}$ & $0.9 \times 10^{-10}$ \\
D79N & $1.9 \times 10^{-10}$ & $1.4 \times 10^{-10}$ \\
E77K & $4.2 \times 10^{-10}$ & $2.6 \times 10^{-10}$ \\
A89V, D78N & $2.9 \times 10^{-10}$ & $1.6 \times 10^{-10}$ \\
A89V, E77K & $1.6 \times 10^{-10}$ & $1.4 \times 10^{-10}$ \\
D78N, E77K & $3.3 \times 10^{-10}$ & $2.9 \times 10^{-10}$ \\
A89V, D78N, E77K & $1.4 \times 10^{-8}$ & $2.3 \times 10^{-8}$ \\
\hline
\end{tabular}

These results indicate that the single mutations have little or no effect on DNA binding, a result which agrees with the in vivo data. The apparent $K_{\mathrm{D}}$ values obtained for the double mutants were also similar to wild-type levels. The triple mutant, however, bound the wild-type operator with a considerably lower affinity $\left(K_{\mathrm{D}}\right.$ $1.4 \times 10^{-8} \mathrm{M}$ in the presence of $\mathrm{Hg}^{\mathrm{II}}$ and $2.3 \times 10^{-8} \mathrm{M}$ in its absence). In vivo this mutant shows the strongest activation in the absence of $\mathrm{Hg}^{\mathrm{II}}$ ( $80 \%$ of wild-type) but its interaction with the DNA is slightly stronger in the presence of $\mathrm{Hg}^{\mathrm{II}}$ as tested in vitro. Thus the triple mutant appears to bind the DNA with approximately 100-fold lower affinity and the effect of $\mathrm{Hg}^{\mathrm{II}}$ on $\mathrm{K}_{\mathrm{D}}$ is reversed with respect to wild-type MerR binding.

\section{Selection and characterization of poorly activating mutants}

E. coli CSH26 $\operatorname{rec} A$ (pAC-90-16, pRZH-18) grows normally on L-agar containing $\mathrm{Kn}, \mathrm{Tc}$ and $\mathrm{X}$-Gal, but slowly, if at all, on the same medium supplemented with $\mathrm{HgCl}_{2}\left(1.0 \mu \mathrm{g} \mathrm{ml}^{-1}\right)$. This may be due to the accumulation of toxic products of X-Gal hydrolysis (Park et al., 1992; Ross et al., 1989) when the promoter is induced, 
and was exploited in the isolation of poorly activating mutants of MerR.

Following hydroxylamine mutagenesis of pAC-90-16 and transformation of $E$. coli CSH26 $\operatorname{crec} A$ (pRZH-18), colonies were isolated on $\mathrm{L}$-agar containing $\mathrm{Kn}, \mathrm{Tc}, \mathrm{X}$ $\mathrm{Gal}$ and $\mathrm{HgCl}_{2}\left(1 \cdot 0 \mu \mathrm{g} \mathrm{ml}^{-1}\right)$. Colonies were grown overnight in L-broth supplemented with $\mathrm{Kn}$ and $\mathrm{Tc}$ and tested for $\beta$-galactosidase activity. Four colonies which failed to induce $\beta$-galactosidase activity were identified and plasmid DNA was prepared from them. The merRcontaining EcoRI fragment was isolated, cloned again into pACYC184 and the phenotype in E. coli CSH26$\Delta \operatorname{rec} A(\mathrm{pRZH}-18)$ was confirmed.

The merR genes from each of the four colonies were sequenced after cloning the EcoRI fragment into M13mp18. Three of the genes contained the same mutation, a $G$ to A transition at nucleotide 475 of $T n 501$, causing a $\mathrm{R} 25 \mathrm{H}$ mutation in MerR; the remaining gene contained a termination codon at position 368 of $\operatorname{Tn} 501$ (resulting in a truncated MerR terminating at A60) and two further mutations in the non-translated downstream region of the gene. The induction of $\beta$-galactosidase activity by one of the three $\mathrm{R} 25 \mathrm{H}$ mutants in the presence and absence of $\mathrm{Hg}^{\mathrm{II}}$ was determined, and compared with isogenic control strains containing the wild-type merR gene (on plasmid pAC-90-16) and lacking merR (plasmid pACYC184). Repression and activation of $\mathrm{P}_{\mathrm{T}}$ by $\mathrm{Hg}^{\mathrm{II}}$ were both severely reduced in the strain containing the $\mathrm{R} 25 \mathrm{H}$ mutant MerR, repression was not detectable, and induction was $2 \%$ of that conferred by wild-type MerR. This is consistent with R25 being in the recognition helix of the helix-turnhelix structure.

\section{DISCUSSION}

Mutants of MerR isolated in our selection procedure contained at least two mutations. It is not clear why this is so, as the site-directed single mutation L74Q gave a slightly higher mercury-independent $\beta$-galactosidase activity than did the selected double mutants A89V-T80P and A89V-G79D. Double mutations arising from the single parents $\mathrm{A} 89 \mathrm{~V}$ or $\mathrm{S} 131 \mathrm{~L}$ may have arisen more frequently than single mutations from the wild-type in our experiments, and the results may merely reflect the limited number of mutants characterized. Moreover, the $\beta$-galactosidase activity assayed in liquid culture does not directly reflect the accumulation of the indole chromophore (and expression of tetracycline resistance) in the plate selection procedures.

A notable feature of the selected mutations is their clustering in the MerR sequence. Inspection of the merR DNA sequence shows no significant changes in base composition which may predispose specific parts of the gene to mutagenesis. Several of the mutations are close to the $\mathrm{Hg}^{\text {II }}$-binding cysteine residues. This is not surprising, as these mutations (when paired with A89V or $\mathrm{S131L}$ ) may partially mimic the effects of $\mathrm{Hg}^{\text {II }}$ binding on MerR conformation and activity. Most of the mutations that pair with A89V (namely L74Q, E77K, D78N, G79S, G79D and T80P) are close to C82, which is thought to be the sole $\mathrm{Hg}^{\mathrm{II}}$-binding cysteine in one MerR subunit of the active homodimer (Helmann $e t$ al., 1990; Shewchuk et al., 1989b) and is proposed to be close to the subunit interface (Shewchuk et al., 1989b). Comess et al. (1994) isolated a A89V-S86C constitutive activator double mutant and showed that this mutant was able to distort the mer operator in the presence or absence of $\mathrm{Hg}^{\mathrm{II}}$. They suggested that the introduction of an additional cysteine may allow the formation of a new disulphide bond to lock the protein into an activating conformation; our data show that nearby mutations can cause activation without generating additional thiol groups.

Only two mercury-independent activating mutations arose from the S131L parent in this work. One (V124A) is a conservative substitution close to the $\mathrm{Hg}^{\mathrm{II}}$-binding cysteine $\mathrm{C} 126$. The other $(\mathrm{R} 62 \mathrm{Q})$ is not close to the $\mathrm{Hg}^{\mathrm{II}}$ binding cysteines in the linear sequence, but may be close to the subunit interface in this protein (Shewchuk et al., 1989a) and therefore affect the activation phenotype.

The P127L mutation is of particular interest as the equivalent residue is conserved in all MerR proteins (data not shown) and it is adjacent to the $\mathrm{Hg}^{\mathrm{II}}$-binding C126. The A89V-P127L double mutant has a strongly activating mercury-independent phenotype. However, it shows only a slight additional activation in the presence of mercury, and the corresponding P127L single mutation confers a very weak mercury-dependent activation phenotype. The single mutation had previously been identified as a reduced activation mutant in the Tn21 MerR (Ross et al., 1989). Summers and colleagues (Livrelli et al., 1993) have shown by in vivo footprinting that the P127L mutant protein has an apparent altered interaction with the RNA polymerase-mer DNA complex and does not show a normal footprinting response to the addition of $\mathrm{Hg}^{\text {II }}$. Thus, it is possible that the P127L mutation may hinder (but not abolish) the binding of $\mathrm{Hg}^{\mathrm{II}}$ by $\mathrm{C} 126$, but be able to potentiate mercury-independent activation in association with A89V. The conserved sequence $\mathrm{CP}(\mathrm{I} / \mathrm{L}) \mathrm{I}$ in all MerR proteins at positions equivalent to C126 to I129 (data not shown) may represent a turn in the MerR tertiary structure.

D78 is conserved in almost all MerR sequences and the D78N single mutation has little activating effect but does slightly reduce activation by $\mathrm{Hg}^{\mathrm{II}}-\mathrm{MerR}$. When combined with other mutations, as in the A89V-D78N and E77K-D78N double mutants, the level of $\mathrm{Hg}^{\mathrm{II}}$ independent activation is higher, but is not as strong as the A89V-E77K or A89V-D78N-E77K mutants. The E77 and D78 acidic residues were targeted, along with two other pairs of acidic residues (D68/E69 and E83/E84), by Comess et al. (1994). In their study the E77 residue was changed to a glutamine rather than the lysine which we isolated by random mutagenesis. It was shown that the E77Q-D78N mutant had no effect by itself but did 
contribute to a repression-deficient phenotype when paired with the E83Q-E84Q mutant. Our results show that the more drastic E77K mutation, especially in conjunction with the D78N and A89V changes, confers a stronger activating phenotype.

A full interpretation of the significance of the individual mutations will eventually require elucidation of the three-dimensional structure of the protein; but, in the absence of a structure, this study can contribute to an understanding of the mechanism of action of MerR. Our data can be rationalized in terms of a model in which MerR exists in two stable conformations when bound to DNA: a repressor conformation (the $R$ state), which represses $\mathrm{P}_{\mathrm{T}}$; and an activator conformation (the $\mathrm{A}$ state), which induces $P_{T}$ and in which the binding of a single ion of $\mathrm{Hg}^{\mathrm{II}}$ alters the equilibrium between the two forms. The mercury-independent mutations are hypothesized to alter the equilibrium in favour of the activator conformation (Parkhill et al., 1993). The strongest support to date for this equilibrium model comes from the incremental mutation series (A89V, A89V-E77K and A89V-E77K-D78N), which shows increased mercury-independent activation through the series, yet further activation of all members of the series can be obtained on the addition of $\mathrm{Hg}^{\mathrm{II}}$. The other two series of single and double mutations, starting with D78N or E77K, show the same effect. We suggest that each mutation slightly displaces the equilibrium in favour of the activator conformation. Within the limits of error of our experiments, wild-type MerR in the presence of $\mathrm{Hg}^{\mathrm{II}}$ may be almost fully in the activator conformation, as only a further $10 \%$ activation over the wild-type induced level of $\beta$-galactosidase expression was detected in our experiments.

The apparent $K_{\mathrm{D}}$ values for the binding of wild-type MerR to DNA $\left(2 \times 10^{-10} \mathrm{M}\right.$ in the presence of $\mathrm{Hg}^{\text {II }}$ and $1 \times 10^{-10} \mathrm{M}$ when $\mathrm{Hg}^{\mathrm{II}}$ is absent) are comparable with the results of Parkhill et al. (1993). The majority of activating mutants in this and in previous studies (Comess et al., 1994) have shown a similar affinity for the operator in the absence of $\mathrm{Hg}^{\mathrm{II}}$. The exception was the strongly activating MerR(A-S) mutant studied by Parkhill et al. (1993), which had a lower affinity for the operator. In all cases the binding of $\mathrm{Hg}^{\mathrm{II}}$ reduced the affinity for the operator DNA. The difference in binding energy of MerR and MerR- $-\mathrm{Hg}^{\mathrm{II}}$ to DNA has been postulated to reflect the free energy required for distortion of the DNA helix (Ansari et al., 1992; O'Halloran et al., 1989). In the studies reported here, the strongest constitutive activator mutant (A89V-D78NE77K) has a significantly lower affinity for the operator than wild-type MerR, and DNA binding is strengthened slightly in the presence of $\mathrm{Hg}^{\mathrm{II}}$. We can interpret these data on a model in which the cumulative mutations displace the structure of the MerR protein towards an activating conformation, but simultaneously destabilize the interaction with the operator. In the case of the triple mutation, the binding of $\mathrm{Hg}^{\mathrm{II}}$ may be required to provide structural stability to MerR and therefore strengthen the protein-DNA interaction.
The mutation $\mathrm{R} 25 \mathrm{H}$ has properties consistent with a defect in the DNA-binding activity of this protein, as both the repression and activation ratios conferred by this protein are much lower than in the wild-type. This mutation provides further evidence that the helix-turn-helix structure predicted to be present between residues I10 and R29 is involved in DNA binding. Our data are consistent with those which indicate that two separate regions of the protein are involved in the binding of DNA and of $\mathrm{Hg}^{\mathrm{II}}$, and in which the mutation E22K reduces DNA binding in vitro about 100-fold (Shewchuk et al., 1989a).

The phenotypes of the parental mutations $A 89 \mathrm{~V}$ and S131L reported here differ from those of the identical mutations in Tn21 (Ross et al., 1989). Both single mutations give rise to higher levels of uninduced expression in vivo in $\operatorname{Tn} 21(24 \%$ and $128 \%$ of wild-type induced activity) than in Tn 501 (both about $5 \%$ of wildtype induced activity). Some of these effects may be due to the differences in protocols for measuring $\beta$-galactosidase activities (e.g. measuring activity in cis or in trans, different host strains, different reporter constructs). However, the differences may also be due to the nine amino acids which differ between the two MerR proteins (Barrineau et al., 1984; Foster \& Brown, 1985; Misra et al., 1984). These are at L34(R), T52(V), R55(K), E77(D), A107(T), R121(K), G135(E), S137(G) and G140(R), where the equivalent $\operatorname{Tn} 21$ residues are given in parentheses. These residues are formally equivalent to multiple mutations in the other protein and one or more of them may give rise to the differences in properties of the wild-type and mutant MerR proteins from Tn501 and $\operatorname{Tn} 21$.

The mutations described here support and provide further evidence for a conformational model for activation of the mer genes by MerR. The MerR dimer binds symmetrically to the dyad sequence (the mer operator) in $\mathrm{P}_{\mathrm{T}}$, one subunit to each operator half-site, and represses transcription from the promoter. On binding $\mathrm{Hg}^{\mathrm{II}}$ across the subunit interface in the Cterminal region of the protein, a conformational change in the MerR dimer occurs, which results in distortion of the DNA at the centre of the operator, through the binding interactions of the each subunit of MerR to each operator half-site on the DNA, and this activates the promoter.

\section{ACKNOWLEDGEMENTS}

This work was supported by Medical Research Council grant number G.9309093CB to N.L.B. We thank Pete Lund, Jim Pittard and Jenny Broome-Smith for plasmids. Ken Jakeman provided help with protein purification. It is a pleasure to acknowledge the helpful comments of Anne Summers on an earlier version of this manuscript.

\section{REFERENCES}

Amann, E., Brosius, J. \& Ptashne, M. (1983). Vectors bearing a hybrid trp-lac promoter useful for regulated expression of cloned genes in Escherichia coli. Gene 25, 167-178. 
Ansari, A. Z., Chael, M. L. \& O'Halloran, T. V. (1992). Allosteric underwinding of DNA is a critical step in positive control of transcription by Hg-MerR. Nature 355, 87-89.

Ansari, A. Z., Bradner, J. E. \& O'Halloran, T. V. (1995). DNA-bend modulation in a repressor-to-activator switching mechanism. Nature 374, 371-375.

Barrineau, P., Gilbert, P., Jackson, W. J., Jones, C. S., Summers, A. O. \& Wisdom, S. (1984). The DNA sequence of the mercuryresistance operon of the IncFII plasmid NR1. J Mol Appl Genet 2, $601-619$.

Bradford, M. (1976). A rapid and sensitive method for the quantitation of microgram quantities of protein utilizing the principle of protein dye-binding. Anal Biochem 72, 248-254.

Brown, N. L., Ford, S. J., Pridmore, R. D. \& Fritzinger, D. C. (1983). Nucleotide sequence of a gene from the Pseudomonas transposon Tn501 encoding mercuric reductase. Biochemistry 22, 4089-4095.

Caslake, L. F., Ashraf, S. I. \& Summers, A. O. (1997). Mutations in the alpha and sigma-70 subunits of RNA polymerase affect expression of the mer operon. J Bacteriol 179, 1787-1795.

Chang, A. C. Y. \& Cohen, S. (1978). Construction and characterization of amplifiable multicopy DNA cloning vehicles derived from the P15A cryptic miniplasmid. J Bacteriol 134, 1141-1156.

Comess, K. M., Shewchuk, L. M., Ivanetich, K. \& Walsh, C. T. (1994). Construction of a synthetic gene for the metalloregulatory protein MerR and analysis of regionally mutated proteins for transcriptional regulation. Biochemistry 33, 4175-4186.

Dodd, I. B. \& Egan, J. B. (1990). Improved detection of helix-turnhelix DNA-binding motifs in protein sequences. Nucleic Acids Res 18, 5019-5026.

Foster, T. J. \& Brown, N. L. (1985). Identification of the merR gene of R100 by using mer-lac gene and operon fusions. J Bacteriol 163 , 1153-1157.

Frantz, B. \& O'Halloran, T. V. (1990). DNA distortion accompanies transcriptional activation by the metal-responsive gene-regulatory protein MerR. Biochemistry 29, 4747-4751.

Harley, C. B. \& Reynolds, R. P. (1987). Analysis of E. coli promoter sequences. Nucleic Acids Res 15, 2343-2361.

Helmann, J. D., Ballard, B. T. \& Walsh, C. T. (1990). The MerR metalloregulatory protein binds mercuric ion as a tricoordinate, metal bridged dimer. Science 247, 946-948.

Heltzel, A., Lee, I. W., Totis, P. A. \& Summers, A. O. (1990). Activator-dependent preinduction binding of $\sigma-70$ RNA polymerase at the metal-regulated mer promoter. Biochemistry 29, 9572-9584.

Ishihama, A. (1993). Protein-protein communication within the transcription apparatus. J Bacteriol 175, 2483-2489.

Livrelli, V., Lee, W. K. \& Summers, A. O. (1993). In vivo DNAprotein interactions at the divergent mercury resistance (mer) promoters. I. Metalloregulatory protein MerR mutants. J Biol Chem 268, 2623-2631.

Lund, P. A. \& Brown, N. L. (1989a). Regulation of transcription in Escherichia coli from the mer and merR promoters in the transposon Tn501. J Mol Biol 205, 343-353.

Lund, P. A. \& Brown, N. L. (1989b). Up-promoter mutations in the positively-regulated mer promoter of Tn501. Nucleic Acids Res 17, 5517-5527.

Lund, P. A., Ford, S. J. \& Brown, N. L. (1986). Transcriptional regulation of the mercury-resistance genes of transposon $\operatorname{Tn} 501$. J Gen Microbiol 132, 465-480.

Miller, J. H. (1972). Experiments in Molecular Genetics. Cold Spring Harbor, NY: Cold Spring Harbor Laboratory.
Misra, T. K., Brown, N. L., Fritzinger, D. C., Pridmore, R. D., Barnes, W. M., Haberstroh, L. \& Silver, S. (1984). Mercuric ionresistance operons of plasmid R100 and transposon Tn501: the beginning of the operon including the regulatory region and the first two structural genes. Proc Natl Acad Sci USA 81, 5975-5979.

O'Halloran, T. \& Walsh, C. (1987). Metalloregulatory DNAbinding protein encoded by the merR gene: isolation and characterization. Science 235, 211-214.

O'Halloran, T. V., Frantz, B., Shin, M. K., Ralston, D. M. \& Wright, J. G. (1989). The MerR heavy-metal receptor mediates positive activation in a topologically novel transcription complex. Cell $\mathbf{5 6}$, 119-129.

Park, S. J., Wireman, J. \& Summers, A. O. (1992). Genetic analysis of the Tn21 mer operator-promoter. J Bacteriol 174, 2160-2171.

Parkhill, J. \& Brown, N. L. (1990). Site-specific insertion and deletion mutants in the mer promoter-operator region of $\operatorname{Tn} 501$; the nineteen base-pair spacer is essential for normal induction of the promoter by MerR. Nucleic Acids Res 18, 5157-5162.

Parkhill, J., Ansari, A. Z., Wright, J. G., Brown, N. L. \& O'Halloran, T. (1993). Construction and characterisation of a mercuryindependent $\mathrm{Mer} R$ activator $\left(\mathrm{MerR}^{\mathrm{AC}}\right)$ : transcriptional activation in the absence of $\mathrm{Hg}(\mathrm{II})$ is accompanied by DNA distortion. EMBO J 12, 413-421.

Praszkier, J., Wilson, I. W. \& Pittard, A. J. (1992). Mutations affecting translational coupling between the rep genes of an IncB miniplasmid. J Bacteriol 174, 2376-2383.

Raibaud, O. \& Schwartz, M. (1984). Positive control of transcription initiation in bacteria. Annu Rev Genet 18, 173-206.

Ross, W., Park, S.-J. \& Summers, A. O. (1989). Genetic analysis of transcriptional activation and repression in the $\operatorname{Tn} 21$ mer operon. J Bacteriol 171, 4009-4018.

Sambrook, J., Fritsch, E. F. \& Maniatis, T. (1989). Molecular Cloning: a Laboratory Manual. Cold Spring Harbor, NY: Cold Spring Harbor Laboratory.

Sanger, F., Nicklen, S. \& Coulson, A. R. (1977). DNA sequencing with chain-terminating inhibitors. Proc Natl Acad Sci USA 74, 5463-5467.

Shewchuk, L. M., Helmann, J. D., Ross, W., Park, S. J., Summers, A. O. \& Walsh, C. T. (1989a). Transcriptional switching by the MerR protein: activation and repression mutants implicate distinct DNA and mercury(II) binding domains. Biochemistry 28, 2340-2344.

Shewchuk, L. M., Verdine, G. L., Nash, H. \& Walsh, C. T. (1989b). Mutagenesis of the cysteines in the metalloregulatory protein MerR indicates that a metal-bridged dimer activates transcription. Biochemistry 28, 6140-6145.

Shewchuk, L. M., Verdine, G. L. \& Walsh, C. T. (1989C). Transcriptional switching by the metalloregulatory MerR protein: initial characterization of DNA and mercury(II) binding activities. Biochemistry 28, 2331-2339.

Spratt, B. G., Hedge, P. J., te Heesen, S., Edelman, A. \& BroomeSmith, J. K. (1986). Kanamycin-resistance vectors that are analogues of plasmids pUC8 pUC9 pEMBL8 and pEMBL9. Gene 41, 337-342.

Stanssens, P., Opsomer, C., McKeown, Y., Kramer, W., Zabeau, M. \& Fritz, H.-J. (1989). Efficient oligonucleotide-directed construction of mutations in expression vectors by the gapped duplex DNA method using alternating selectable markers. Nucleic Acids Res 17, 4441-4454.

Utschig, L. M., Bryson, J. W. \& O'Halloran, T. V. (1995). Mercury199 NMR on the metal receptor site in MerR and its protein-DNA complex. Science 286, 380-385. 
Wright, J. G., Tsang, H.-T., Penner-Hahn, P. \& O'Halloran, T. V. (1990). Coordination chemistry of the Hg-MerR metalloregulatory protein: evidence for a novel tridentate $\mathrm{Hg}$-cysteine receptor site. J Am Chem Soc 112, 2434-2435.

Yanisch-Perron, C., Viera, J. \& Messing, J. (1985). Improved M13 phage cloning vectors and host strains: nucleotide sequences of the M13mp18 and pUC19 vectors. Gene 33, 103-119.

Received 22 April 1998; revised 10 June 1998; accepted 17 June 1998. 